\title{
Training-related accidents during teacher-student-assistance activities of medical students
}

\author{
Acidentes relacionados ao treinamento durante a atividade \\ docente-discente-assistencial de estudantes de medicina
}

\begin{abstract}
José Mauro Barbosa Reis ${ }^{1}$, Adilson Lamounier Filho ${ }^{1}$, Cristiano Ângelo Rampinelli ${ }^{1}$, Eliane Cristina de Souza Soares ${ }^{1}$, Renata da Silva Prado ${ }^{1}$ e Ênio Roberto Pietra Pedroso ${ }^{2}$
\end{abstract}

\begin{abstract}
Asurvey was done to determine the most common hospital accidents with biologically contaminated material among students at the Medical College of the Federal University of Minas Gerais. Six hundred and ninety-four students (between fifth and twelfth semesters of the college course) answered the questionnaire individually. Three-hundred and forty-nine accidents were reported. The accident rate was found to be $33.9 \%$ in the third semester of the course, and increased over time, reaching $52.3 \%$ in the last semester. Sixty-three percent of the accidents were needlestick or sharp object injuries; $18.3 \%$ mucous membrane exposure; $16.6 \%$ were on the skin, and $1.7 \%$ were simultaneously on the skin and mucous membrane exposure. The contaminating substances were: blood (88.3\%), vaginal secretion (1.7\%), and others (9.1\%). The parts of the body most frequently affected were: hands $(67 \%)$, eyes $(18.9 \%)$, mouth $(1.7 \%)$, and others $(6.3 \%)$. The procedures being performed when the accidents occurred were: suture (34.1\%), applying anesthesia (16.6\%), assisting surgery ( $8.9 \%)$, disposing of needles $(8.6 \%)$, assisting delivery $(6.3 \%)$, and others (25.9\%). Forty-nine percent of those involved reported the accident to the accident control department. Of these $29.2 \%$ did not receive adequate medical assistance. Eight percent of those involved used antiretroviral drugs and of these $86 \%$ discontinued the treatment on receiving the ELSA method applied to the patient ( HVVnegative); $6.4 \%$ discontinued the treatment due to its side-effects; and 16\% completed the treatment.
\end{abstract}

Key-words: Human Immunodeficiency Virus. Medical students. Needlestick injuries. Aids.

\section{RESUM0}

Este estudo transversal foi realizado para avaliar acidentes com material biologicamente contaminado entre estudantes de medicina da Universidade Federal de Minas Gerais. Foi aplicado um questionário individual de resposta espontânea e sigilosa, em 694 (43,4\%) estudantes do quinto ao décimo segundo semestres do curso médico. Foram relatados 349 acidentes, com aumento progressivo de 33,9 até 52,3\% entre os estudantes do quinto ao décimo primeiro períodos, respectivamente. Cerca de $63 \%$ dos acidentes foram com agulha ou objeto cortante; $18,3 \%$ afetando mucosas; $16,6 \%$ a pele; $1,7 \%$ simultaneamente a pele e a mucosa. Os contaminantes principais foram sangue (88,3\%) e secreção vaginal $(1,7 \%)$. As regiões do corpo mais freqüentemente afetadas foram as mãos (67\%), olhos (18,9\%), boca $(1,7 \%)$ e outras $(6,3 \%)$. Os procedimentos realizados no momento em que 0 acidente ocorreu foram sutura $(34,1 \%)$, administração de anestesia $(16,6 \%)$, participação em cirurgia como observador $(8,9 \%)$, punção de veia com agulha $(8,6 \%)$, observação de parto $(6,3 \%)$ e outros $(25,9 \%)$. 0 setor de biossegurança da instituição foi procurado por $49 \%$ dos acidentados para a busca de providências pertinentes à cada caso. Destes estudantes, $29,2 \%$ não receberam assistência médica considerada adequada e esclarecedora para sua situação. Cerca de $8 \%$ dos estudantes receberam antiretrovirais, destes 86\% descontinuaram 0 tratamento com o resultado do exame ELISA rápido feito no paciente fonte (VIH-negativo); 6,4\% descontinuaram 0 tratamento devido aos efeitos colaterais das drogas usadas e 16\% completaram corretamente 0 tratamento.

Palavras-chaves: Virus da Imunodeficiência Humana. Estudantes de medicina. Lesões provocadas por agulhas. Sida.

\footnotetext{
1. Faculdade de Medicina da Universidade Federal de Minas Gerais. 2. Departamento de Clínica Médica da Faculdade de Medicina da Universidade Federal de Minas Gerais, Belo Horizonte, MG.

Address to: Dr. Enio R.P. Pedroso. DCM/FM/UFMG. Av. Alfredo Balena 190/4 andar, Santa Efigênia, 30130-100 Belo Horizonte, MG, Brasil.

Tel: 5531 3248-9400

e-mail: enio@medicina.ufmg.br

Recebido para publicação em 29/4/2002

Aceito em 16/7/2004
} 
Circumstances in Brazil oblige medical students to participate in activities that ordinarily only professionals would do in many countries. In their eagerness to learn more, students may also get involved in extracurricular activities too early. Such cases are poorly supervised. Some Brazilian researchers have investigated HIV infection among hospital workers, but none specifically deal with students ${ }^{5}{ }^{8}$. These peculiarities highlight the need to evaluate the risk of medical students contracting diseases from patients in the hospital during their teacher-student-assistance work.

The risk of transmitting human immunodeficiency virus ( HIV) as a result of a single percutaneous exposure to contaminated material is considered low. The Centers for Disease Control estimated this risk to be $0.4 \%$. The fact that every health professional is continuously exposed increases the risk factor. Based on previously published seroconversion rates, estimated numbers of accidents, and estimated number of HIV-positive patients, it is possible to calculate the annual contamination index for students. This fluctuates between 27 and 46 per 100,000 individuals ${ }^{10}$. Personal accidents, the leading cause of death in this age group, has an equivalent death toll.

Several reports evaluate accidental HIV exposure 710111214 . The research difficulties include recall bias, the limited scope of the survey, the chance of obtaining inaccurate information, and the subjective nature of the responses. Some retrospective studies have been conducted, interviewing students that reported exposure to potentially contaminated material ${ }^{811}$. Others used a daily questionnaire to overcome recall bias ${ }^{14}$. Still others, including this study, distributed questionnaires to a sample number of students ${ }^{70^{12}}$. In spite of the difficulties involved in each research method they can all provide valuable information.

This study had the objective of evaluating the risk of medical students to accidental exposure to potentially infected material in a hospital setting during their undergraduate training activities and their access to biosafety measures whenever necessary.

\section{MATERIAL AND METHODS}

Students were studied at the Medical College/UFMG ( between fifth and twelve semesters). Multiple-choice questionnaires were used, distributed individually by the researchers just before theoretical classes for each level. The form was completed spontaneously and handed back at the end of the class period. All the research was done from October to December, 1999. To prevent anyone from participating twice, one of the opening questions asked whether the student had already answered the questionnaire, in which case it was excluded.

The questionnaire was made up of two parts: the first consisted of a question about whether the student had already suffered an accident with biologically contaminated material; the second part was only answered by students who had in fact been involved in such an accident.

In the second part, students were asked to answer a specific questionnaire about each accident they recalled, regarding the type of accident, contaminating material, body part affected, hospital setting where the accident occurred, and subsequent procedures that were undertaken. It was possible to mark more than one option as an answer to the questions about the use of personal protection equipment (barrier use) and about the factors that contributed to the accidental exposure. It was asked if the student reported the accident to the medical center and what procedures they followed.

The sample calculated was based on an estimate of the accident rate. Each semester of the medical course required its own estimate. These estimates, set by a previous study ${ }^{13}$. Calculations were done using Epi Info program ${ }^{2}$ to determine the minimum sample necessary to establish statistical significance for each semester. The $8 \%$ margin of error was adopted. This information is shown in Table 1.

The sample obtained was analyzed by the Epi Info program². Those interviewed as well as those who declined to participate were guaranteed their identities would not be disclosed.

\section{RESULTS}

The total number interviewed represented a significant sample of the population.

The rate at which students between fifth and twelve semesters of the medical course suffered accidents with potentially blood-contaminated material was found to be $34.2 \%$ (236/691) (Table 1). The rates according to each semester are given in Table 2.

The total number of accidents reported by 236 students was 349: $63.3 \%(221 / 349)$ were needlestick or sharp object injuries; $18.3 \%$ (64/349) mucous membrane exposure; $16.6 \%$ (58/349) on the skin; and 1.7\% (6/349) simultaneously on the skin and mucous membrane.

The hospital setting which presented the highest number of accidents was the small wounds sector, with $42.1 \%$ of the cases (Table 3) . The contaminating materials were: blood, 88.3\% (308/ 349) of the accidents; vaginal secretion, 1.7\% (6/349); nasal

Table 1 - The calculated sample of students for each semester of themedical course at the Medical College of the Federal University of Minas Gerais showing the estimated of the accident rate with potentially contaminated material in hospital setting during 1999.

\begin{tabular}{lcccc}
\hline $\begin{array}{l}\text { Semester of the } \\
\text { medical course }\end{array}$ & $\begin{array}{c}\text { Total number } \\
\text { of students }\end{array}$ & $\begin{array}{c}\text { Estimated } \\
\text { accident rate (\%) }\end{array}$ & $\begin{array}{c}\text { Necessary } \\
\text { sample }\end{array}$ & $\begin{array}{c}\text { Total of those } \\
\text { interviewed }\end{array}$ \\
\hline Fifth & 172 & 3 & 16 & 58 \\
Sixth & 172 & 3 & 16 & 66 \\
Seventh & 156 & 15 & 51 & 87 \\
Eighth & 164 & 25 & 67 & 107 \\
Ninth & 166 & 45 & 78 & 113 \\
Tenth & 162 & 50 & 78 & 113 \\
Eleventh & $82^{*}$ & 60 & 53 & 61 \\
Twelth & 169 & 65 & 78 & 86 \\
\hline Total & 1,243 & - & 437 & 691 \\
\hline
\end{tabular}

*80 students were participating in health related rural area programs and did not participate in this study 
Table 2 - Accident rate by semester of the medical course with potentially blood-contaminated material in hospital setting at the Medical College of the Federal University of Minas Gerais during 1999.

\begin{tabular}{lcccc}
\hline \multirow{5}{*}{$\begin{array}{l}\text { Semester of the } \\
\text { medical course }\end{array}$} & \multicolumn{2}{c}{$\begin{array}{c}\text { Number of accidents/ } \\
\text { students (NA) }\end{array}$} & $\begin{array}{c}\text { Number of students } \\
\text { interviewed (N) }\end{array}$ & $\begin{array}{c}\text { Accident } \\
\text { Rate (NA/N X 100) }\end{array}$ \\
\cline { 2 - 3 } absolute & $\%$ & & 58 & 3.4 \\
Fifth & 2 & 0.8 & 58 & 9.1 \\
Sixth & 6 & 2.5 & 66 & 13.8 \\
Eeventh & 12 & 5.1 & 87 & 25.2 \\
Eighth & 27 & 11.4 & 107 & 43.4 \\
Ninth & 49 & 20.9 & 113 & 53.1 \\
Tenth & 60 & 25.4 & 113 & 57.4 \\
Eleventh & 35 & 14.8 & 61 & 52.3 \\
Twelth & 45 & 19.1 & 86 &
\end{tabular}

Table 3 - The hospital settings which presented the highest number of accidents with potentially blood-contaminated material at the Medical College of the Federal University of Mnas Gerais during 1999.

\begin{tabular}{lcc}
\hline Hospital Setting & Number of accidents & Percentage \\
\hline Small wounds sector & 147 & 42.1 \\
Maternity & 78 & 22.3 \\
Surgery unit & 46 & 13.2 \\
Out-patient surgery unit & 36 & 10.4 \\
Intensive care unit & 13 & 3.7 \\
Patient ward & 12 & 3.4 \\
First aid unit & 6 & 1.7 \\
Others & 11 & 3.2 \\
\hline Total & 349 & 100.0 \\
\hline
\end{tabular}

secretion, 1.1\% (4/349); bloodless pus, 1.1\% (4/349); others, $6.9 \%$ (24/349). The most affected body parts were: hands, $67 \%$ (234/349); eyes, 18.9\% (66/349); mouth, 1.7\% (6/349); eyes and mouth, 2\% (7/349); others 6.3\% (22/349).

Four percent (14/349) of the accidents occurred while the student was not using personal protection equipment. The frequency with which gloves, gowns, masks, and goggles were used is shown in Table 4.

Table 4: Use of personal protection equipment during 349 accidents with potentially blood-contaminated material in hospital setting at the Medical College of the Federal University of Minas Gerais during 1999.

\begin{tabular}{lcc}
\hline Equipment & Frequency of the use of personal protection & Percentage \\
\hline Gloves & 313 & 89.7 \\
Gowns & 226 & 64.8 \\
Masks & 172 & 49.3 \\
Goggles & 115 & 33.0 \\
None & 14 & 4.0 \\
\hline
\end{tabular}

Suturing accounted for 34\% (119/349) of the accidents and was the most frequent form of exposure to accidents. The rate at which other procedures resulted in accidents is given in Table 5.

Table 6 shows that the greatest factor contributing to accidents was carelessness, with 44.7\% (156/349).

Forty-nine percent (173/349) of the accidents were reported to the health center. Of these, $57 \%$ considered they did not receive adequate assistance.

Nine percent (31/349) of those involved in accidents used a antiretroviral drugs. Seventy seven percent (24/31)
Table 5 - Procedures which involved the most frequent accidental exposures with potentially blood-contaminated material in hospital setting at the Medical College of the Federal University of Minas Gerais during 1999.

\begin{tabular}{lcc}
\hline Procedures & Number of accidents & Procedure rate (\%) \\
\hline Suturing & 119 & 33.8 \\
Applying local anesthesia & 58 & 16.6 \\
Assisting surgery & 31 & 8.9 \\
Recapping needle & 30 & 8.6 \\
Assisting delivery & 22 & 6.3 \\
Handling needle case & 12 & 3.4 \\
Handling knife & 6 & 1.7 \\
Others & 69 & 19.8 \\
Did not respond & 2 & 0.6 \\
\hline Total & 349 & 19.7 \\
\hline
\end{tabular}

Table 6 - Factors contributing to 349 accidents with potentially bloodcontaminated material in hospital setting at the Medical College of the Federal University of Minas Gerais during 1999 as reported by the students.

\begin{tabular}{lcc}
\hline Factors contributing to accidents & Number of accidents & Percentage \\
\hline Carelessness & 156 & 45.3 \\
Lack of experience & 108 & 30.9 \\
Carelessness of others & 101 & 28.9 \\
Lack of personal protection equipment & 49 & 14.4 \\
Long work hours & 43 & 12.3 \\
Poor instructions & 31 & 8.9 \\
Inadequate facilities & 19 & 5.4 \\
Other factors & 17 & 4.9 \\
\hline
\end{tabular}

discontinued the treatment after receiving the blood test results of the patient involved; $6.4 \%$ (2/31) discontinued the treatment due to its side effects; $16 \%$ (5/31) complied with the treatment completely.

\section{DISCUSSION}

The accident rate for medical students with potentially contaminated material is high, although it is lower than that of medical interns ${ }^{10}$. About one third of the population surveyed were involved in accidents. During the final semesters of the course, more than half of the students suffered some kind of accident involving blood. The data collected here are similar to those observed at the University of California, USA, where $65 \%$ of the medical students had been involved in some kind of accident by the end of the course ${ }^{11}$. Blood transmitted viruses, such as HIV, hepatitis B, and hepatitis C, are not uncommon in such cases. This demonstrates the great ethical responsibility of medical teaching institutions.

The impact of training, awareness programs, and supervision to reduce accident risk has been analyzed by some studies ${ }^{11}{ }^{14}$. In spite of determined effort by the institution to train students to avoid accidents during teacher-student activities, the University of California continued to have a high accident rate among students ${ }^{31}$, due to factors that are inherent to medical learning. Natural student anxiety as they treat patients is one of the factors that goes beyond the control of precautionary training. Extensive training on mannequins, emotional support, and extra teacher attention during teacher- 
student assistance activities could play a decisive role in reducing the risk of accidental HIV exposure.

Despite these questions, the medical curriculum should prepare students without exposing them to unacceptable risks. The medical teaching institution should guarantee adequate instruction to the pupils as well as working toward this objective in other ways. Forbidding students to have contact with HIV positive patients is considered unethical and a poor teaching method ${ }^{3}$. Post-accident prophylaxis, however has been proven to reduce the risk of HIV contamination ${ }^{14}$, and should, in such circumstances, be considered a priority and made easily available, including technical and emotional support, as well as medical follow up.

\section{REFERENCES}

1. Cardo DM, Culver DH, Ciesielski JL. Srivastava PU, Marcus R. A case-control study of HIV seroconversion in health care workers after percutaneous exposure. New England Journal of Medicine 337:1485-1490, 1997.

2. Dean AG, Dean JA, Coulombier D. Centers for Disease Control and Prevention (CDC). Epi Info version 6,04, 1994.

3. Federman DD. Protecting the future of Medicine - from themselves. Annals of Internal Medicine 130:66-67, 1999.

4. Gerberding JL. Management of occupational exposure to blood-borne viruses. New England Journal of Medicine 332:444-451, 1995.

5. Gir E, Costa FPP, Silva AM. A enfermagem frente a acidentes de trabalho com material potencialmente contaminado na era do HIV.
Revista da Escola de Enfermagem da Universidade de São Paulo 32:262272, 1998.

6. Hermann RC. Risks of HIV exposure to medical students and health care personnel. Journal of American Medical Association 264: 1187-1192, 1990

7. Keita-Perse O, Pradier C, Rosenthal E, Altare J, Cassuto JP, Dellamonica P. Hospital medical students: a population at risk for accidental exposure to blood. Presse Medicale 27: 1723-1726, 1998.

8. Machado AA, Costa JC, Gir E, Moriya TM, Figueiredo FC. Risco de infecçäo pelo vírus da imunodeficiência humana ( HIV) em profissionais de saúde. Revista de Saúde Pública 26: 54-56, 1992.

9. Marcus R. Surveillance of health care workers exposed to blood from patients infected with the human immunodeficiency virus. New England Journal of Medicine 319: 1118-1123, 1998.

10. O'Neill TM, Abbott AV, Radecki SE. Risk of needlesticks and occupational exposures among residents and medical students. Archives of Internal Medicine 152:1451-1456, 1992.

11. Osborn HE, Papadakis MA, Gerberding JL. Occupational exposures to body fluids among medical students. A 7-year longitudinal study. Annals of Internal Medicine 130:45-51, 1999.

12. Resnic SF, Noerdlinger MA. Occupational Exposure Among Medical Students and House Staff at a New York City Medical Center. Archives of Internal Medicine 155:75-80, 1995.

13. Soares ES, Salles JA, Prado RS, Pedroso ERP. Avaliação dos comportamentos de risco de estudantes de medicina em relação à síndrome de imunodeficiência adquirida. In: Resumos do XXXV Congresso da Sociedade Brasileira de Medicina Tropical, 1999. Revista da Sociedade Brasileira de Medicina Tropical 32 ( supl I) : 350, 1999.

14. Wong ES, Stotka JL. Are Universal Precautions Effective in Reducing the Number of Occupational Exposures Among Health Care Workers? Journal of American Medical Association 265:1123-1128, 1991. 